\title{
Røysundersøkelser i Løten, Hedmark
}

\author{
CHRISTIAN LØCHSEN RØDSRUD, \\ JAKOB KILE-VESIK OG JULIAN POST-MELBYE
}

Løchsen Rødsrud, C., Kile-Vesik, J. \& Post-Melbye, J. 2020. Excavations and interpretations of cairns in Løten, Hedmark. AmS-Varia 61, 99-114, Stavanger, ISSN 0332-6306, ISBN 978-82-7760-187-8

In 2015, the Museum of Cultural History organized a large excavation project in Løten, Hedmark with over 90 sites. During the project both clearance cairns and cairns interpreted as graves were excavated. The field at Skillingstad contained more than 100 cairns, of which approximately 40 were excavated. Although originally thought to be clearance cairns, results obtained over the course of the excavation demanded that this interpretation be reconsidered. In the area surrounding Skillingstad, four smaller cairn fields were also excavated, ranging in size from 4 to 21 cairns. Several of these were associated with small, oval, bowl-shaped fields that overlapped in time with the graves at Skillingstad. The plant macrofossil analyses returned few interesting results, but the cairns containing graves and the clearance cairns differed significantly in their micromorphological results. In addition, there were clear differences in structural organization and the relationship between the cairns in the grave and clearance fields respectively. The burial cairns were spread evenly across the site, built with uniform sized rocks and placed with respect to older monuments such that none of the monuments merged into larger units. In contrast, the clearance cairns were more randomly distributed across the site, sometimes cleared to one side of the field and at other sites in between the cultivated land and pastures. The rocks in these cairns were also more variable in size and often several cairns had grown together over time. We will also share some administrative experiences based on the reinterpretation from clearance cairns to graves at Skillingstad.

Christian Løchsen Rødsrud, Museum of Cultural History, University of Oslo, N-0130 OSLO. E-mail: chrislro@khm.uio.no Jakob Kile-Vesik, Museum of Cultural History, University of Oslo, N-0130 OSLO. E-mail: j.j.e.kile-vesik@khm.uio.no Julian Post-Melbye, Museum of Cultural History, N-0130 OSLO. E-mail: jrmartin@khk.uio.no

Keywords: cairns, burial or clearance, Early Iron Age, site sampling, site organization

\section{Introduksjon og problemstilling}

I 2015 gjennomførte Kulturhistorisk museum et stort utgravningsprosjekt i Løten og Elverum, Hedmark med over 90 lokaliteter (Bergstøl \& Loftsgarden, 2014; Lønaas, Mjærum, Rundberget, Gundersen, \& Bergstøl, 2014). Bakgrunnen var at Statens vegvesen planla ny riksveg $3 / 25$. Det ble undersøkt både rydningsrøyser og gravrøyser i større og mindre omfang, og i denne artikkelen vil vi rette fokus mot forskjellen mellom de to kategoriene i et landskap der de kan fremstå ganske like. Spesielt i så måte var undersøkelsen av et røysfelt på Skillingstad med over 100 røyser. I utgangspunktet var de tolket som rydningsrøyser, men feltundersøkelsene viste at røysene måtte tolkes som graver, slik at problemstillingene måtte endres underveis i prosjektet. Rundt Skillingstad ble det også undersøkt fire mindre røysfelt. De varierte i størrelse fra 4 til 21 røyser. Flere av disse lå i tilknytning til små skålformede åkrer som hadde overlappende brukstid med gravrøysene som ble undersøkt.

Innledningsvis vil vi gi en kort presentasjon av arkeologisk kunnskap om Løten, før vi vil diskutere de enkelte røyslokalitetene. Vi vil begynne med rydningsrøysene og en kort faghistorisk gjennomgang, før de gjeldende lokalitetene blir beskrevet og diskutert. Vår hovedproblemstilling er knyttet til gravfeltet på Skillingstad, og hvordan det må forstås. Til slutt vil vi sammenstille det arkeometriske datagrunnlaget fra prosjektet og tegne opp noen lange linjer i forståelsen av landskapet der de ulike utgravningsobjektene har sin plass. Det vil legges spesiell vekt på forståelsen av røysfeltet på Skillingstad, der røysundersøkelsene viser hvordan det er mulig å følge livsløpet til en gård, uten at selve tunområdet er avdekket. Vi vil også diskutere 
administrative erfaringer med bakgrunn i omtolkningen av rydningsrøyser til gravrøyser på Skillingstad.

\section{Tidligere undersøkelser i Løtendistriktet}

Landskapet Hedemarken omfatter Hamar, Ringsaker, Stange og Løten kommuner, men flertallet av arkeologiske utgravninger er foretatt i de tre førstnevnte. Det rike kulturmiljøet rundt maktsetet på Åker er behandlet en rekke steder i faglitteraturen. Særlig kjent er Åker-funnet fra tidlig merovingertid (Grieg, 1918; Slomann \& Christensen, 1984; Hagen, 1992; Nybruget, 1992; Solberg, 2000, s. 200-201). Gården Åker ligger strategisk og sentralt plassert med tanke på ferdselen på Mjøsa, men også som knutepunkt for ferdsel på kongevegen fra Viken til Gudbrandsdalen samt østover mot Østerdalen og Värmland, med kontinuitet fra 200-tallet e.Kr. og opp i yngre jernalder (Pilø, 2005). Åker ble ytterligere undersøkt i 2016, men resultatene derfra er ennå ikke publisert. En lokalitet som også bør nevnes, er Lille Børke i Ringsaker med funn av minst tre hustufter, kokegroper og en grop med to nedgravde romerske glass (Lislerud \& Stene, 2007).

De mest kjente undersøkelsene i Løten er gravfeltet på By som ble ledet av Nicolay Nicolaysen i 1879-1881. Feltet omfatter 250 gravminner og er med dette et av de største gravfeltene vi har på indre Østlandet, og det eneste store gravfeltet som er kjent i distriktet. Det var i kontinuerlig bruk fra omkring Kristi fødsel og inn i vikingtid. 104 av de utgravde haugene ble definert som gravminner, mens 18 mindre, undersøkte røyser er tolket som rydningsrøyser (Martens, 1969, s. 15).

I tidsrommet 1993-2010 er det gjennomført enkelte mindre undersøkelser i Løten kommune. I 1993-1994 ble det undersøkt kokegroper og ildsteder datert til førromersk jernalder, romertid og vikingtid, et kokesteinslag fra folkevandringstid, et langhus fra vikingtid, samt graver fra merovingertid og gravrøyser fra vikingtid i forbindelse med utbygging av rv. 3 Mågård-Haukstad (Risbøl, 1997). I 2004 ble det undersøkt en kokegrop og et ildsted med dateringer til romertid innenfor et gravfelt på Karud søndre (Reitan, 2007), mens det i 2006 ble gravd ut et bryggesteinslag på Balke med datering til 660-880 e.Kr. (Helliksen, 2007). I 2009 ble det undersøkt bryggesteinslag, dyrkningslag og kokegroper med dateringer til merovingertid og høymiddelalder, samt kokegroper med dateringer til førromersk jernalder i forbindelse med fv. 166 Brenneriroa-Veenkrysset (Wenn, 2010). $\varnothing$ vrige undersøkelser i Løten har i hovedsak omfattet gravminner, og undersøkelsene ligger mer enn 20 år tilbake i tid uten tilgjengelige rapporter.
Sammenlignet med nærliggende områder som Romerike i sør og Mjøstraktene i vest, er kunnskapen om gårdsbosetningen og utmarksbruken i forhistorisk tid og middelalder i Løten mangelfull. Resultatene fra undersøkelsene på Skillingstad og omegn vil være et kjærkomment tilskudd til den videre forståelse av jernalderens bosetning på Hedmarken, særlig i randsonen mot utmarksområdene i Løten.

\section{Forskningshistorie gravrøyser og rydningsrøyser}

Av eldre kilder får man inntrykk av at røysfelt har vært vanlig i store deler av Hedmark og Oppland. Gerhard Schøning (1778) omtaler mange felt som kan være sammenlignbare med feltet på Skillingstad. Det kan være grunn til å trekke frem Aurtande i Lesja og Einangfeltet på Gardberg i Vestre Slidre. Disse har også både gravrøyser og rydningsrøyser, og mange av gravene er funnfattige, slik tilfellet synes å være på Skillingsstad. Mange av feltene som inneholdt det Schøning omtaler som «brolagte kredse», ser ut til å være fjernet ved nybrottsarbeid.

Rydningsrøyser og ubestemte røysfelt har ledet til mye arkeologisk hodebry. Spesielt innenfor forvaltningen ettersom røysenes alder var vanskelig å avklare, og dermed var det ikke enkelt å avgjøre om de var eldre enn fredningsgrensen for automatisk fredete kulturminner (Kulturminneloven $₫ 3$ ). Det var opplagt at det hadde blitt ryddet jord i Norge siden jordbrukets introduksjon i sen-neolitikum, men rydningens form hadde endret seg lite frem til mekaniseringen av jordbruket. Omfanget av bevart, forhistorisk åkermark var følgelig uvisst, og det var utfordrende å sette grenser og begrunne fredning av feltene. Hørdalsåsen $\mathrm{i}$ Vestfold ble en viktig lokalitet i forståelsen av hvordan fossil åkermark kunne undersøkes, og det store kunnskapspotensialet som lå i dette. (Denne) lokaliteten ble undersøkt både på slutten av 1980-tallet (Pedersen, 1990) og på 2000-tallet (Mjærum, 2012). Spesielt ved utgravningene i 2009 og 2010 ble det foretatt et omfattende prøveuttak i sammenheng med ekstensiv flateavdekking av åkerarealer og detaljstudier av profiler. Avdekking av åkrene i plan, i kombinasjon med profilgravning, ga en bedre forståelse av prøveuttakenes kontekst. Spesielt bruk av mikromorfologiske analyser bidro til å belyse forskjellige typer jordbearbeiding innenfor åkersystemet. Uten denne typen analyser blir forskjellene vanskeligere å fange opp. Godt bevarte åkersystemer fra jernalderen er også kjent fra det indre Østlandet. Ingunn Holm finner det sannsynlig at dyrkningsfeltet i Grundsetmarka i Elverum er tatt i 
bruk i eldre jernalder. Dette baserer hun på dateringer, mulige funn og skålgroper og to antatte gravrøyser blant rydningsrøysene (Holm, 2004, s. 114; Holm \& Berg-Hansen, 2007).

I den eldste fasen i Grundsetmarka er den mest sannsynlige driftsformen busktrede (Holm, 2004, s. 120). Mer intensivt bruk med gjødsling er mer sannsynlig i løpet av middelalderen (Holm, 2004, s. 121). Verdt å merke seg er at det ser ut som feltet har ligget øde gjennom yngre jernalder (Holm, 2004, s. 122). Ved bruk av gjødsel blir jordbruket uløselig knyttet til husdyrhold, mens busktrede kan utføres uten dette forbeholdet (Mjærum, 2012, s. 112). Ut fra funn både i Norge og Sverige er det blitt argumentert for at enkelte av rydningsrøysfeltene er spor etter et relativt ekstensivt jordbruk, med sykluser på flere tiår, avsviing og minimal gjødsling (Holm, 1995, s. 133-139; Gren, 2003, s. 162-163; Holm 2007, s. 336-337). Ved et slikt rotasjons(land)bruk vil det være behov for store arealer, og lang tids drift kan resultere i omfattende steinrydding. Hørdalsåsen er forstått som en mer syklisk bruk mellom intensiv og ekstensiv utnyttelse (Mjærum, 2012, s. 112). Senere bruk av samme åkerarealer vil bidra til å redusere sporene etter de eldste bruksfasene, og følgelig er siste bruksfase enklest å fange opp og forstå. På røysfeltene i Løten ble disse erfaringene lagt til grunn for undersøkelsen, både på de små dyrkningslokalitetene og på Skillingstad. Erfaringene fra undersøkelsen er at denne tilnærmingen hjelper tilå skille mellom gravskikk med få bevarte spor og rydningsrøyser.

\section{Gjærlu, Prestegården og Skramstad}

I 2015 ble det undersøkt fire mindre lokaliteter med dyrkningsspor (Fig. 1). To av disse på lå på Skramstad, (benevnt nord og sør,) en på Gjærlu og en på Prestegården. Disse røysfeltene bestod av små, avgrensede flater i svakt hellende terreng med varierende orientering. Til sammen var det syv adskilte dyrkningsflater. De ryddede flatene var mellom 200 og $400 \mathrm{~m}^{2}$ (og røysene var anlagt lite systematisk). På Prestegården var alle steinene ryddet ut til en side i en streng av rydningsrøyser, mens på Gjærlu, Skramstad nord og sør var det lagt opp røyser spredt og uten klar systematikk. På disse feltene var det flere eksempler på at to røyser overlappet hverandre. Rydningsrøysene lå ikke øverst eller nær toppen av de dyrka hellingene. Røysene var gjennomgående små, inntil 3,5 m i diameter.

Aktivitetene på de mindre lokalitetene ble datert til eldre jernalder og 1500-/1600-tallet e.Kr. (se figur 6). På alle feltene var det et opphold i sporbar aktivitet

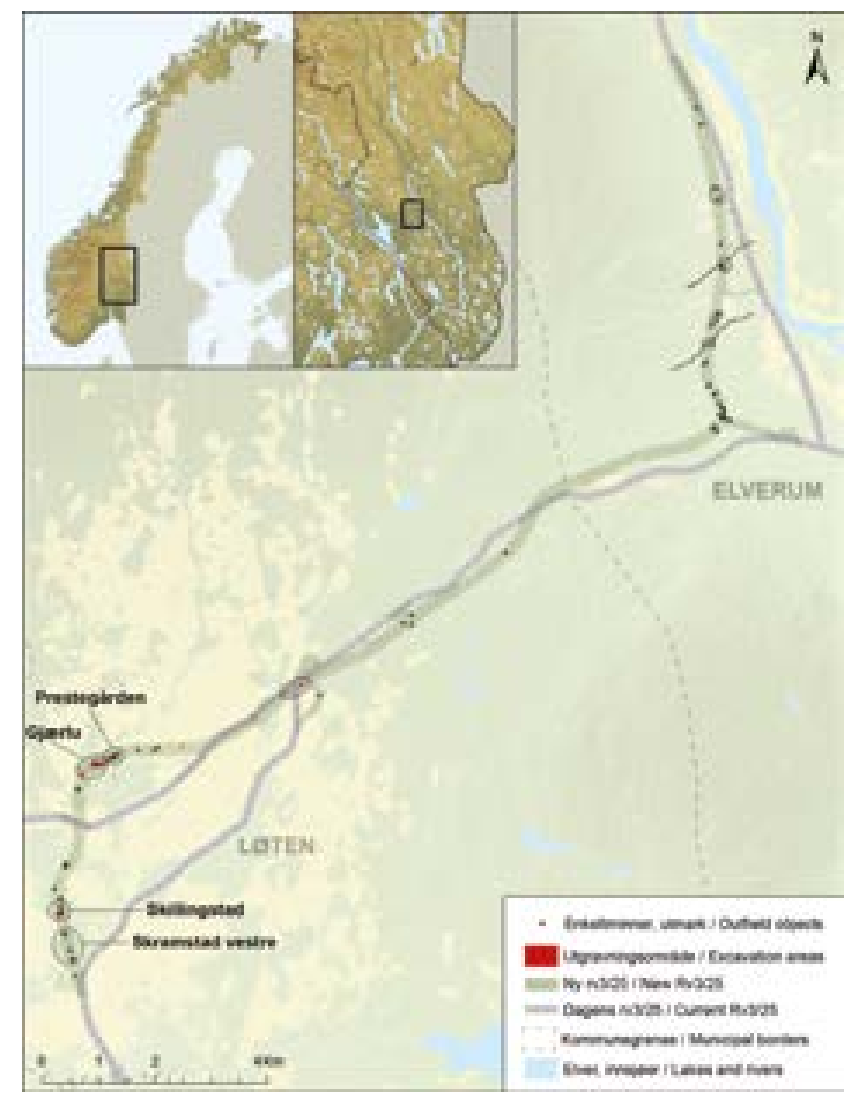

Fig. I. Oversikt over lokaliteter som nevnes i teksten. Fig. I. Overview of excavation sites mentioned in the text.

i sen vikingtid og første halvdel av middelalderen. Sammenfallende med oppholdet i dyrkningen i middelalderen ble det anlagt kullgroper på alle feltene. På Skramstad nord dekket for eksempel vollen på en kullgrop deler av en rydningsrøys, og på Gjærlu var en røys dekket av kull etter tømming av en kullgrop.

\section{Gravfeltet på Skillingstad}

I 2009 registrerte Hedmark fylkeskommune et felt med 109 strukturer, deriblant 100 røyser, sju kullgroper og to tjæremiler på gården Skillingstad (Engtrø, 2009). Hele dette feltet ble imidlertid ikke undersøkt ved utgravningene i 2015, da kun deler av lokaliteten ble påvirket av veiutbyggingen (Fig. 2). I den vestre delen av Skillingstadfeltet ligger flere større røyser. Disse er sannsynligvis også graver og viser at gravfeltets utbredelse er langt større enn den delen som er undersøkt i $ø$ st. I den utgravde delen ligger de yngste gravene lengst mot øst og antyder en fortettingsprosess fra sentrum av feltet og ut mot de østre yttergrensene av ryggen der gravrøysene lå plassert. Det kan spekuleres i om den vestre delen av feltet rommer flere røyser fra eldre jernalder, eller om det har foregått en tilsvarende fortetting der. Dette lar seg imidlertid ikke besvare uten ytterligere utgravning 
Fig. 2. Undersøkte røyser på Skillingstad. Fig. 2. Excavated cairns at Skillingstad.
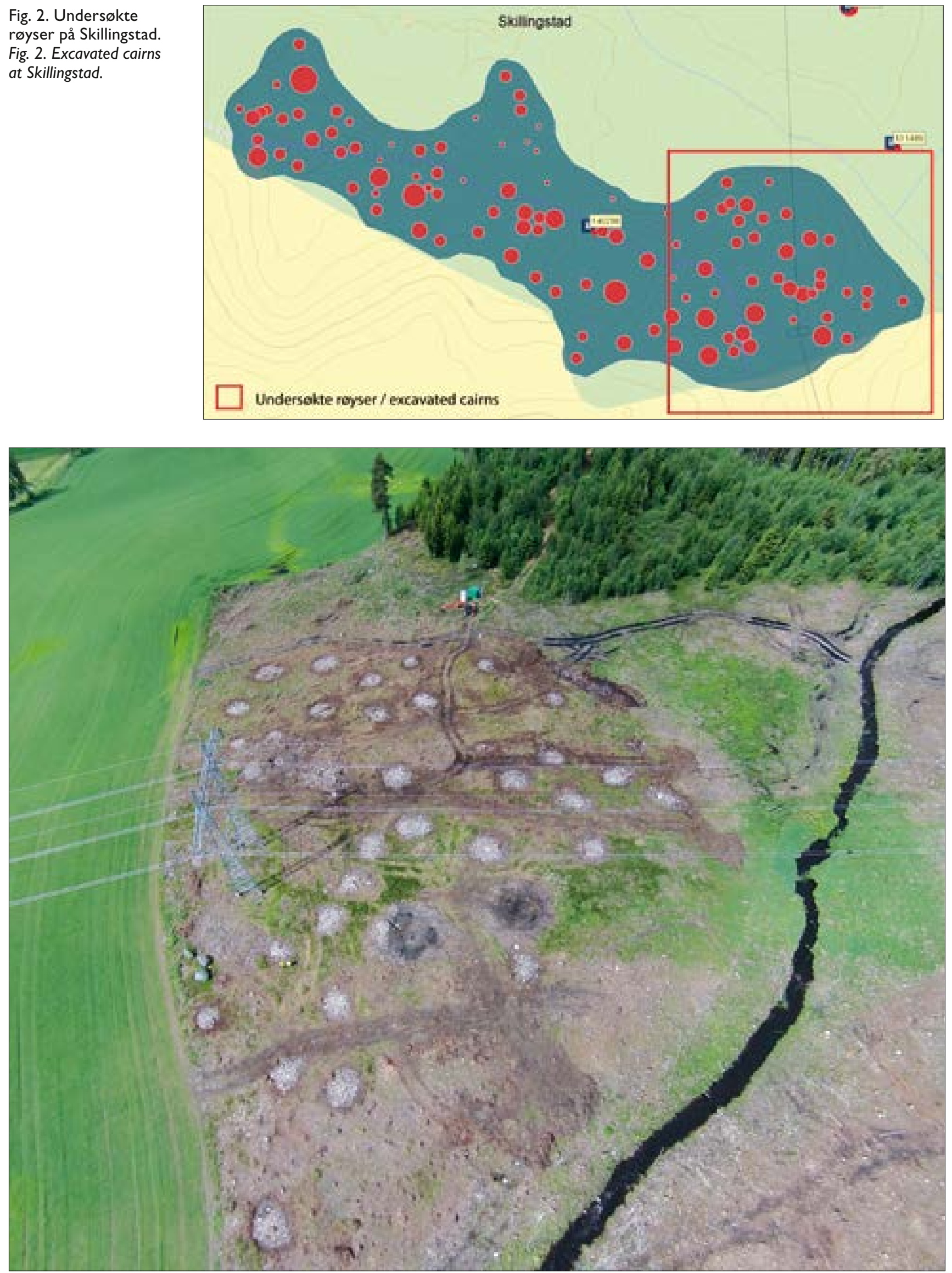

Fig. 3. Dronefotografi over røysfeltet på Skillingstad. To kullgroper er også godt synlige på bildet. Foto: Magne Samdal, KHM. Fig. 3. Drone photography of the cairns at Skillingstad. Two charcoal pits are also visible on the photo. Photo: Magne Samdal, KHM. 
Området som skulle undersøkes, omfattet 35 av de registrerte røysene og tre kullgroper (Lønaas et al., 2014). I forbindelse med utgravningen fremkom ytterligere seks røyser. Disse ble funnet ved flateavdekking mellom de registrerte røysene og helt i ytterkanten av feltet. Enkelte var også delvis fjernet av den tilgrensende åkeren. Dette innebærer at feltet opprinnelig har vært noe større enn det som registreringen viser. Ikke bare ligger det flere røyser innenfor det registrerte feltet, men trolig har også flere røyser forsvunnet i forbindelse med jordbruksvirksomhet i området.

Røysenes alder ble ikke avklart ved registreringene, og det var derfor noe uenighet om utgravningsbudsjettets størrelse mellom Kulturhistorisk museum og Riksantikvaren i prosjekteringsfasen. Ved utgravningens oppstart var derfor røysenes alder et viktig tema å avklare. Vollene til to kullgroper lå over røyser på feltet, og en datering av kullgropene ville derfor kunne gi en pekepinn om røysenes alder. Det ble sendt inn trekull fra en av kullgropene som ble datert til 1050-1250 e.Kr. (Beta-414949) (Kile-Vesik under arbeid). Dette ga en fremre datering av røysene, men mye tydet på at røysene kunne være betydelig eldre. Trolig har røysene vært helt overgrodde før kullgropene ble anlagt, da man neppe med vilje har lagt gropene et sted der man var nødt til å grave seg gjennom et tykt lag med stein.

Før røysene ble undersøkt, ble det gjort ni prøvestikk mellom røysene for å skaffe en oversikt over lagdannelsen mellom røysene og dermed fastslå potensialet for eventuell dyrkning på feltet. Prøvestikkene fremviste imidlertid en ren podsolprofil uten synlige spor etter forhistoriske dyrkningslag. Etter prøvestikking ble det fokusert på å rense frem alle røysene på feltet for å skaffe bedre oversikt over landskapsrommet. Det ble da klart at så godt som hele flaten var utnyttet, og at ingen av røysene gikk over i hverandre (jf. Fig. 3). Videre var de oppbygd av relativt jevnstor stein, men enkelte tok utgangspunkt i større jordfast stein på feltet. Dette står i kontrast til rydningsrøysene som ble undersøkt på andre felt som Gjærlu, Prestegården og Skramstad, der røysene ofte ble funnet spredt, noen ganger sammenvokst eller ryddet til en side av feltet. Som regel var også steinene i rydningsrøysene mer blandet i størrelse enn røysene på Skillingstad.

Registreringsrapporten beskrev lokaliteten som et felt med rydningsrøyser, der enkelte røyser skilte seg noe ut og muligens kunne representere graver (Hansen, 2012, s. 46). Før utgravningens oppstart var skogen på feltet hogget ned, og strukturene kom tydeligere frem. Røysene var alle fine og runde i formen, og de lå ikke tett på hverandre (Fig. 3). Den metodiske fremgangsmåten ble derfor justert fra begynnelsen av feltarbeidet, slik at røysene ble gravd for hånd fremfor å bli snittet med gravemaskin. Allerede i første røys ble det gjort funn av en kniv og en nål av jern, samt en gjenstand av bly. Røysen hadde i tillegg spor etter en kantkjede. Dette forsterket inntrykket av at det var graver, og ikke rydningsrøyser, på feltet, og alle røysene på feltet ble derfor håndgravd. Metodisk ble røysene gravd lagvis i motstånde kvadranter for å få gjennomgående profiler. Dersom spor av indre konstruksjoner hadde fremkommet under gravningen, var planen å grave de aktuelle kvadrantene ned til tilsvarende nivå for å dokumentere det indre gravgjemmet. Det ble imidlertid ikke avdekket ytterligere konstruksjonselementer. Steinpakningen gikk helt ned til marknivå i alle røysene. De fremgravde nivåene ble gått over med metalldetektor mellom hvert mekaniske lag. Etter at profilene var dokumentert og prøver tatt ut, ble de to gjenstånde kvadrantene gravd på samme måte. Røysene var primært dekket av nedfall fra barskogen som lå på feltet, og fremrensingen av feltet ble effektivisert gjennom bruk av løvblåser. Løvblåsing av røyser var et metodisk grep som lettet den manuelle opprensingen mellom steiner. Metoden var arbeidsbesparende og kan anbefales ved fremtidige gravninger av røyser i skog. Da hele feltet var ryddet, ble det tatt oversiktsbilder av området med drone, og det ble laget en fotogrammetrimodell.

Åtte av de undersøkte røysene var forholdsvis små og skilte seg ut ved en mindre forseggjort konstruksjon samt mangel på kantkjede og funn. Disse enklere røysene ligger delvis samlet inn mot en myr nord for feltet, lengst unna det området som var dyrket på utgravningstidspunktet. Ut fra oppbyggingen er det uvisst om disse representerer rydningsrøyser eller en enklere form for graver, men det helhetlige og ryddige uttrykket på røysfeltet forsterker sannsynligheten for at de har vært graver. Siden det ikke ble funnet spor etter dyrkning inne på røysfeltet, er avstanden fra kjent åkermark uforholdsmessig stor sett fra et rydningsperspektiv. Området kan imidlertid godt ha fungert som beitemark både før og samtidig med at feltet ble brukt til gravlegging.

Alle røysene varierte fra 2 til $8 \mathrm{~m}$ i diameter, men med en gjennomsnittlig størrelse på mellom 4 og 6 m (se Tabell 1). Største høyde var opp mot 0,5 m. I 16 tilfeller lå det en stor, jordfast stein i midten av røysen. Generelt lå diameteren på steinene i røysene mellom $10 \mathrm{og} 20 \mathrm{~cm}$. Steinen i kantkjedene lå på ca. $40 \mathrm{~cm}$. Av de 41 undersøkte røysene hadde 29 kantkjede, og det fremkom funn i 13 av dem. Ingen lag eller konstruksjonselementer ble påtruffet inni røysene, men 
Tabell I. Oversikt over røyser, funn og dateringer fra Skillingstad.

Table I. Overview of cairns, finds and datings from Skillingstad.

\begin{tabular}{|c|c|c|c|c|c|c|c|}
\hline \multicolumn{8}{|c|}{$\begin{array}{l}\text { Gravrøyser } \\
\text { Burial cairns }\end{array}$} \\
\hline A-nr. & $\begin{array}{l}\text { Størrelse } \\
\text { Size } \\
\text { diameter } \\
\text { meter }\end{array}$ & $\begin{array}{l}\text { Kantkjede/ } \\
\text { Peristalith/ } \\
\text { Kerb stones }\end{array}$ & $\begin{array}{l}\text { Jordfast } \\
\text { stein }\end{array}$ & $\begin{array}{l}\text { Gjenstander } \\
\text { Artefacts }\end{array}$ & $\begin{array}{l}\text { Vedart } \\
\text { Wood } \\
\text { species }\end{array}$ & $\begin{array}{l}\text { Datering } \\
\text { Dating, I } \sigma\end{array}$ & $\begin{array}{l}\text { Datering } \\
\text { Dating, } 2 \sigma\end{array}$ \\
\hline AlOI & $4-6,6-8$ & & & Fragment & $\begin{array}{l}\text { Bartre/Furu/ } \\
\text { Coniferous/ } \\
\text { Pine }\end{array}$ & $\begin{array}{l}1040-1100,1110-1170 \\
\text { e.Kr./AD }\end{array}$ & $1030-1190$ e.Kr./AD \\
\hline Al02 & $4-6,6-8$ & $x$ & & $\begin{array}{l}\text { Kniv, Søm, Fragment } \\
\text { Knife, Horseshoe nail, } \\
\text { Fragment }\end{array}$ & $\begin{array}{l}\text { Bartre/Furu/ } \\
\text { Coniferous/ } \\
\text { Pine }\end{array}$ & I640-1655 e.Kr./AD & $\begin{array}{l}\text { 1520-1575, I630-1665, } \\
1785-1795 \text { e.Kr./AD }\end{array}$ \\
\hline Al03 & $4-6$ & $x$ & & & & & \\
\hline Al05 & $4-6$ & $\mathrm{X}$ & & Fragment & & & \\
\hline Al06 & $2-4,4-6$ & $\mathrm{x}$ & & & $\begin{array}{l}\text { Løvtre/ } \\
\text { Deciduous }\end{array}$ & $\begin{array}{l}355-285,230-200 \\
\text { f.Kr./BC }\end{array}$ & $360-170$ f.Kr./BC \\
\hline Al07 & $4-6$ & $x$ & & $\begin{array}{l}\text { Kniv, Fragment } \\
\text { Knife, Fragment }\end{array}$ & $\begin{array}{l}\text { Selje/Osp } \\
\text { Willow/Aspen }\end{array}$ & $425-540$ e.Kr./AD & $415-560$ e.Kr./AD \\
\hline Al08 & $4-6$ & $x$ & & $\begin{array}{l}\text { Nøkkel, Bein } \\
\text { Key, Bones }\end{array}$ & Bjørk/Birch & $400-425$ e.Kr./AD & $\begin{array}{l}385-475,485-535 \\
\text { e.Kr./AD }\end{array}$ \\
\hline Al09 & $4-6$ & $x$ & & & Furu/Pine & $5710-5630$ f.Kr./BC & $5725-5620$ f.Kr./BC \\
\hline Allo & $2-4,4-6$ & $x$ & $x$ & Fragment & & & \\
\hline Al12 & $4-6$ & $\mathrm{X}$ & $\mathrm{X}$ & & & & \\
\hline AlI3 & $6-8$ & $x$ & $x$ & $\begin{array}{l}\text { Kniv, Nål, Fragment } \\
\text { Knife, Pin, Fragment }\end{array}$ & $\begin{array}{l}\text { Selje/Osp } \\
\text { Willow/Aspen }\end{array}$ & 535-405 f.Kr./BC & $\begin{array}{l}735-690,660-645 \\
545-400 \text { f.Kr./BC }\end{array}$ \\
\hline All4 & $4-6$ & $x$ & & $\begin{array}{l}\text { Pinsett, Spiker, Bein } \\
\text { Tweezers, Nails, Bones }\end{array}$ & Bjørk/Birch & $\begin{array}{l}420-475,485-535 \\
\text { e.Kr./AD }\end{array}$ & 400-545 e.Kr./AD \\
\hline AlI5 & $4-6,6-8$ & $x$ & $x$ & Kjetting/Link fragment & & & \\
\hline Al16 & $2-4,4-6$ & $\mathrm{x}$ & & & & & \\
\hline$A|2|$ & $2-4$ & $x$ & & Slagg/Slag & $\begin{array}{l}\text { Løvtre } \\
\text { Deciduous }\end{array}$ & I35-240 e.Kr./AD & $\begin{array}{l}125-255,300-315 \\
\text { e.Kr./AD }\end{array}$ \\
\hline $\mathrm{A} \mid 22$ & $4-6$ & $x$ & $x$ & & $\begin{array}{l}\text { Bartre } \\
\text { Coniferous }\end{array}$ & $\begin{array}{l}\text { 1690-1730, I8I0-1890, } \\
1900-1930 \text { e.Kr./AD }\end{array}$ & $\begin{array}{l}\text { 1645-1680, I735-1800, } \\
1935-1950 \text { e.Kr./AD }\end{array}$ \\
\hline $\mathrm{A} / 24$ & $2-4,4-6$ & $x$ & & & Furu/Pine & $\begin{array}{l}1490-1530,1550-1640 \\
\text { e.Kr./AD }\end{array}$ & I470-1650 e.Kr./AD \\
\hline$A \mid 26$ & $4-6$ & $x$ & & $\begin{array}{l}\text { Fragment, Keramikk, } \\
\text { Bein/Fragment, Ceramics, } \\
\text { Bones }\end{array}$ & Bjørk/Birch & $\begin{array}{l}200-155,135-115 \text { f.Kr./I } \\
\text { BC } 650-700,740-770 \\
\text { e.Kr./AD }\end{array}$ & $\begin{array}{l}345-320,205-85,75- \\
55 \text { f.Kr./BC, } 650-730 \\
740-770 \text { e.Kr./AD }\end{array}$ \\
\hline$A \mid 28$ & $4-6$ & $x$ & $x$ & & & & \\
\hline Al29 & $4-6$ & $x$ & $x$ & & $\begin{array}{l}\text { Løvtre } \\
\text { Deciduous }\end{array}$ & $\begin{array}{l}40 \text { f.Kr./BC-30 e.Kr./ } \\
\mathrm{AD}, 40-50 \text { e.Kr./AD }\end{array}$ & 50 f.Kr - 65 e.Kr./AD \\
\hline$A|3|$ & $4-6$ & $x$ & & & & & \\
\hline Al32 & $4-6$ & $\mathrm{x}$ & & & Osp/Aspen & $\begin{array}{l}4675-4635,4615-4545 \\
\text { f.Kr./BC }\end{array}$ & $4690-4520$ f.Kr./BC \\
\hline $\mathrm{A} \mid 33$ & $4-6$ & $x$ & $x$ & Søm/Horseshoe nail & Bjørk/Birch & $\begin{array}{l}380-355,285-230 \\
\text { f.Kr. } / B C\end{array}$ & $\begin{array}{l}395-345,320-205 \\
\text { f.Kr./BC }\end{array}$ \\
\hline $\mathrm{Al} 34$ & $2-4,4-6$ & $\mathrm{X}$ & & & $\begin{array}{l}\text { Furu, Gran/ } \\
\text { Pine, Spruce }\end{array}$ & $\begin{array}{l}1510-1600,1610-1640 \\
\text { e.Kr./AD }\end{array}$ & I480-1650 e.Kr./AD \\
\hline Al35 & $4-6$ & $x$ & $x$ & & & & \\
\hline Al37 & $4-6$ & $\mathrm{X}$ & & & Furu/Pine & $\begin{array}{l}475-485,535-570 \\
\text { e.Kr./AD }\end{array}$ & $425-600$ e.Kr./AD \\
\hline Al 40 & $2-4,4-6$ & & & & Selje/Willow & $\begin{array}{l}665-690,750-760 \\
\text { e.Kr./AD }\end{array}$ & $\begin{array}{l}655-725,740-770 \\
\text { e.Kr./AD }\end{array}$ \\
\hline
\end{tabular}




\begin{tabular}{|c|c|c|c|c|c|c|c|}
\hline \multicolumn{8}{|c|}{$\begin{array}{l}\text { Gravrøyser } \\
\text { Burial cairns }\end{array}$} \\
\hline A-nr. & $\begin{array}{l}\text { Størrelse } \\
\text { Size } \\
\text { diameter } \\
\text { meter }\end{array}$ & $\begin{array}{l}\text { Kantkjede/ } \\
\text { Peristalith/ } \\
\text { Kerb stones }\end{array}$ & $\begin{array}{l}\text { Jordfast } \\
\text { stein }\end{array}$ & $\begin{array}{l}\text { Gjenstander } \\
\text { Artefacts }\end{array}$ & $\begin{array}{l}\text { Vedart } \\
\text { Wood } \\
\text { species }\end{array}$ & $\begin{array}{l}\text { Datering } \\
\text { Dating, I } \sigma\end{array}$ & $\begin{array}{l}\text { Datering } \\
\text { Dating, 2 } \sigma\end{array}$ \\
\hline Al42 & $4-6$ & & $x$ & Nål/Pin & Furu/Pine & $\begin{array}{l}6905-6885,6825-6695 \\
\text { f.Kr./BC }\end{array}$ & $\begin{array}{l}7030-6875,6865-6685 \\
\text { f.Kr./BC }\end{array}$ \\
\hline Al83 & $2-4$ & $x$ & & & & & \\
\hline Al84 & $2-4,4-6$ & $x$ & $x$ & & & & \\
\hline Al 86 & $2-4,4-6$ & $x$ & & & Furu/Pine & $\begin{array}{l}1520-1590,1620-1650 \\
\text { e.Kr./AD }\end{array}$ & I490-1650 e.Kr./AD \\
\hline Al 87 & $4-6$ & & & & Furu/Pine & $\begin{array}{l}\text { I490-I530, I550-1640 } \\
\text { e.Kr./AD }\end{array}$ & I470-1640 e.Kr./AD \\
\hline Al96 & $2-4$ & $x$ & & & & & \\
\hline \multicolumn{8}{|c|}{$\begin{array}{l}\text { Enklere } \\
\text { røyser } \\
\text { Simple cairns }\end{array}$} \\
\hline A-nr. & $\begin{array}{l}\text { Størrelse } \\
\text { Size } \\
\text { diameter } \\
\text { meter }\end{array}$ & $\begin{array}{l}\text { Kantkjede } \\
\text { Peristalith/ } \\
\text { Kerb stones }\end{array}$ & $\begin{array}{l}\text { Jordfast } \\
\text { stein }\end{array}$ & $\begin{array}{l}\text { Gjenstander } \\
\text { Artefacts }\end{array}$ & $\begin{array}{l}\text { Vedart } \\
\text { Wood } \\
\text { species }\end{array}$ & $\begin{array}{l}\text { Datering } \\
\text { Dating, I } \sigma\end{array}$ & $\begin{array}{l}\text { Datering } \\
\text { Dating, } 2 \sigma\end{array}$ \\
\hline Al04 & $2-4$ & & $x$ & & Furu/Pine & $\begin{array}{l}1450-1510,1600-1615 \\
\text { e.Kr./AD }\end{array}$ & I455-1645 e.Kr./AD \\
\hline Al17 & $4-6,6-8$ & & & & & & \\
\hline $\mathrm{A} 120$ & $2-4$ & & $x$ & & & & \\
\hline $\mathrm{A} / 23$ & $4-6$ & & $x$ & & & & \\
\hline $\mathrm{A} / 30$ & $2-4,4-6$ & & $x$ & & $\begin{array}{l}\text { Bartre } \\
\text { Coniferous }\end{array}$ & $\begin{array}{l}\text { 1660-1680, I765-1800, } \\
1940-1950 \text { e.Kr./AD }\end{array}$ & $\begin{array}{l}\text { I650-1685, I730-I8I0, } \\
1925-1950 \text { e.Kr./AD }\end{array}$ \\
\hline Al39 & $4-6$ & & & & & & \\
\hline Al76 & $2-4$ & & $x$ & & & & \\
\hline A197 & $2-4$ & & & & & & \\
\hline
\end{tabular}

de nederste lagene med stein hadde en del jordmasser omkring seg. Gravene kunne se ut til å være gravd ned i undergrunnen, men dette skyldes trolig naturlige prosesser. Bioturbasjon (jordganger skapt av mark og gnagere) kan ha skapt tomrom under røysene som igjen er blitt presset sammen av tyngden av stein i røysene slik at røysen synker ned og gir inntrykk av å være nedgravd. Frost kan skape en liknende situasjon ved at jordmassene ekspanderer slik at steinene igjen graver seg ned i marken.

Det ble ikke oppdaget tydelige nedgravninger under noen av røysene. Selve begravelsen må derfor ha blitt anlagt over undergrunnen. Det fremkom ikke bein av arkeologisk interesse, bare yngre dyrebein, men det kan skyldes at bevaringsforholdene i røysene var ekstremt dårlige. Røysene var homogent oppbygd, og det ble ikke påvist indre gravkonstruksjon i noen av dem. Det var så få funn i hver røys at funnspredning ikke kunne kobles til plasseringen av avdøde. Røysene besto primært av stein, og regn og vind kunne dermed lett trenge inn i røysene og bryte ned gjenstander og organisk materiale.
God tilgang på oksygen fremskynder forråtnelse av organisk materiale og oksidering/korrosjon av metaller, og på Skillingstad skaper jordbunnsforholdene med åpne steinrøyser en situasjon der oksygen og nedbør kommer lett i kontakt med gjenstandene. I tillegg til det ovennevnte kunne representanter for Statens vegvesen bekrefte forekomster av alunskifer og svartskifer i undergrunnen på Skillingstad. Alunskifer er en såkalt reaktiv bergart. Ved å eksponere alunskiferen vil oksygenet i eventuelt vann og/eller luft starte en kjemisk reaksjon i bergarten. Sulfider i alunskifer vil reagere med vann og danne svovelsyre. Slike syredannende bergarter fører med seg en rekke miljømessige problemstillinger, men kan også være en medvirkende årsak til dårlige bevaringsforhold for gjenstander i røysene.

I løpet av undersøkelsen ble det samlet inn totalt 46 funn, deriblant fire kniver, en nøkkel, to pilspisser og fire nåler som kan ha fungert som feste til spenner. Det fremkom også 12 jerngjenstander som ikke kunne bestemmes nærmere (Tabell 1). I en av røysene ble det funnet keramikkskår av et udekorert forrådskar og 


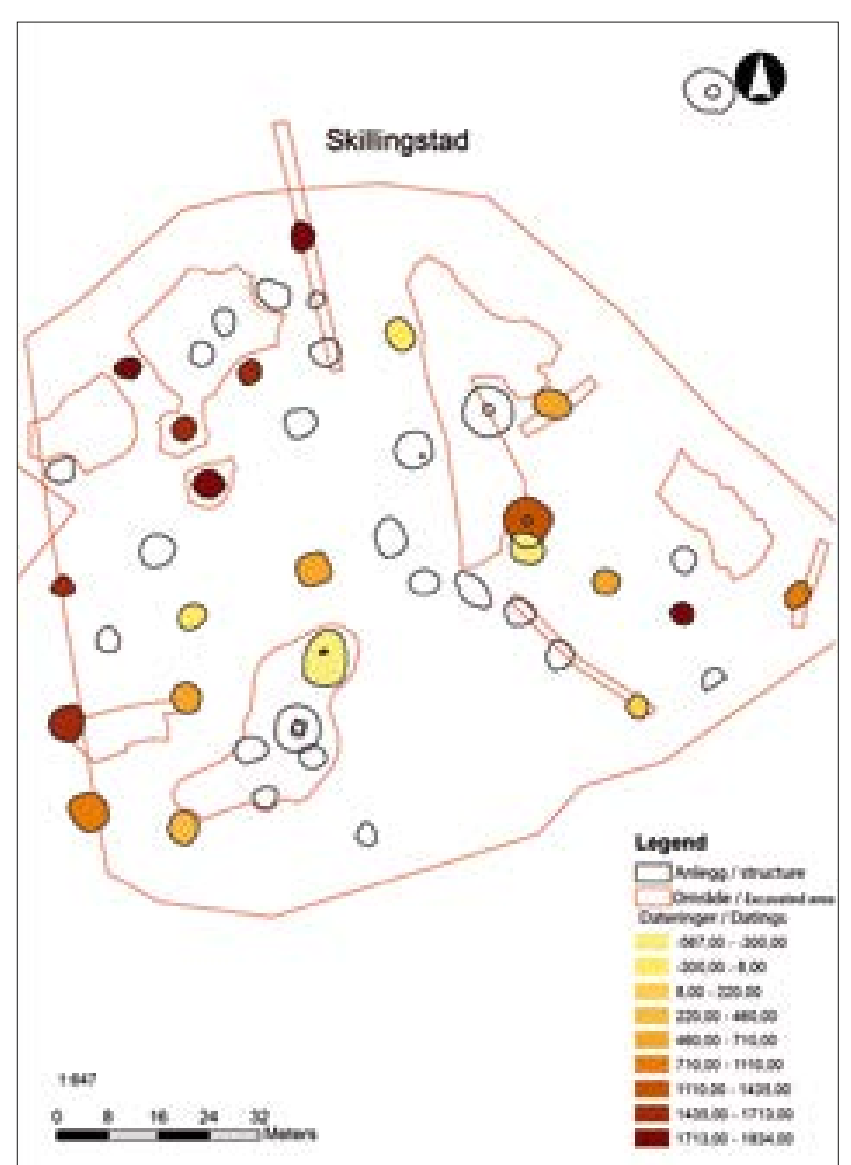

Fig. 4. Oversiktskart over utgravningsfeltet på Skillingstad. Fig. 4. Map of the excavated section of the cairn site at Skillingstad.

svært fragmenterte biter av noe som kan være brente bein, men funnene er dessverre tapt. En stor del av funnene lå i utkanten av røysene, mellom eller under kantsteinene. De ble funnet både iblandet steinlagene og iblandet jorden som de nederste lagene med sten hadde gravd seg ned i, men aldri i separate nedgravninger under røysene. Det var ikke mulig å trekke noen videre sluttsatser ut fra funnenes plassering. Det ble også gjort funn med detektor i jorden utenfor gravene, plassert tett opp mot kantkjeden. Av spesiell interesse i så måte er en kniv og to pilspisser fra merovingertid. Muligens kan dette være spor etter ofringer til ære for de døde, en form for gjenbruk av et eldre gravfelt.

Røysene på Skillingstad har flere likhetstrekk med gravene fra eldre jernalder på By-feltet (Martens, 1969), noen kilometer unna. Flertallet av gravminnene var runde røyser, hvor flere av dem har fotkjede. By-feltet var i drift gjennom hele jernalderen, og også rikere graver fra yngre jernalder er godt representert. Det mer begrensete funnmaterialet fra gravene datert til eldre jernalder har imidlertid klare paralleller med funnmaterialet fra Skillingstad. Med hensyn til gravskikken i eldre jernalder skriver Martens (1969, s. 36-37) at «Etter alt å dømme har altså brannflak, urnebranngroper, vanlige branngroper og urnegraver vert benyttet ved siden av hverandre under hele eldre jernalder, og $i$ noen tilfeller finner vi flere gravformer representert $i$ samme haug. Alle de gravene vi hittil har behandlet, har vort dekket av runde røyser. De fleste røysene har vart nokså lave og et flertall av dem har hatt fotkjede». Forskjellen mellom antatte skjelettbegravelser på Skillingstad og ulike kremasjonsbegravelser på By er distinkt, men røysene har klare ytre likhetstrekk. Selve røysene på Skillingstad er noe enklere enn det man ser på By, med mindre fremtredende konstruksjonselementer og dimensjoner, men samtidig er røysene på Skillingstad veldig homogene. Røysene her har varierende størrelse, men de aller fleste er oppbygd på samme måte med tilsvarende kantkjeder og fordeling av stein.

Det ble gjennomført metallurgiske analyser av tre av funnene fra røysene. Den analyserte kniven er trolig av lokalprodusert jern, mens nøkkelen og en pilspiss har metallsignaturer som antyder et opphav i det sørlige Sverige (Jouttijärvi, 2017; Kile-Vesik, under arbeid). Dette til tross for at det ligger flere faglig undersøkte jernfremstillingsplasser i nærområdet (Ånestad, Id. 141255 og Englaug Østre, Id. 159683) som er fra samme tidsrom som Skillingstad.

Dateringene fra Skillingstad viser at feltet har vært i bruk gjennom hele eldre jernalder (se også Tabell $1 \mathrm{og}$ Fig. 4), med oppstart like etter at feltet ryddes i yngre bronsealder/førromersk jernalder (735 f.Kr. til 600 e.Kr.) og deretter jevn spredning av dateringer utover på 2-300-tallet e.Kr. I folkevandringstid kan det se ut som at bruken av røysfeltet intensiveres, mens det siden avtar med to dateringer til merovingertid (655 og 770 e.Kr.). Disse to røysene ligger lengst ute på den østre spissen av feltet, like før terrenget heller ned mot myrlendt område rundt en bekk, og kan representere gravfeltets siste fase. Merovingertidsdateringene sammenfaller med funnene av de to pilspissene som dateres til samme tid. I løpet av merovingertiden går gravfeltet ut av bruk, og landskapet gror igjen.

Det finnes ingen dateringer fra vikingtid, og det ser ut til at røysfeltet også glemmes i folks minne. Det bør imidlertid bemerkes at de undersøkte røysene kun er en del av et større felt, og at det kan ligge flere graver fra yngre jernalder i den vestre delen av lokaliteten som ennå ikke er utgravd. I tidlig middelalder ble det drevet med kullproduksjon i området. Det ble anlagt flere kullgroper inne på røysfeltet, og det er registrert flere kullgroper i nærheten. Kullgropene på feltet er datert til mellom 1050 og 1250 e.Kr. (Kile-Vesik, under arbeid). I to tilfeller er kullgropene plassert oppå røyser, noe som tyder på at gravfeltet på den tiden var helt ute 
av bruk, og at røysene ikke ble respektert i forbindelse med konstruksjon av kullgroper. Etter bruken av kullgropene ser vi en ny fase der området ligger urørt før det igjen avsvis og ryddes på 15-1600-tallet. De yngste dateringene fra feltet ligger mellom 1415 og 1795 e.Kr. (Kile-Vesik, under arbeid) og stammer fra trekull som ble innsamlet fra toppen av røysene (og inne blant steinene i enkelte røyser). Tilsvarende dateringer er gjort på et avsviingslag under en moderne røys, Id. 140905, fra et nærliggende felt med rydningsspor på Skramstad. Det brente kullet fra toppen av røysene på Skillingstad kan derfor stamme fra samme avsviingshendelse, da jorden igjen ble brutt opp til jordbruksformål (trolig beite) etter en lang periode med skog.

Dateringene er gjort på trekull fra makrofossilprøver tatt i bunnen av profilene gjennom røysene. Konteksten her er imidlertid uklar, og det er usikkert om resultatene daterer selve røysa eller kullmateriale fra gammel markoverflate under røysa. Enkelte av de eldste dateringene kan derfor representere avsviing i forbindelse med at området ryddes for bruk eller eventuelt eldre ildsteder som ble benyttet før røysene ble anlagt.

Omtrent $350 \mathrm{~m}$ sør for det undersøkte området, på nabogården Skramstad, ligger et kokegropfelt (se Fig. 5), Id. 141268 (Hansen, 2012). Jernalderdateringene fra Skillingstad sammenfaller med dateringene av disse kokegropene, og trolig bør de to feltene ses i sammenheng med hverandre. På den bakgrunn forstår vi gravfeltet på Skillingstad som en plass av stor betydning, og vi tror at flere gårder må ha hatt tilknytning til Skillingstad/Skramstad som samlingssted. Mangelen på dateringer mellom 770 og 1050 e.Kr. kan enten forklares ved at de aktuelle gårdene ble forlatt, eller at andre områder ble tatt i bruk til gravlegging.

\section{Oppsummering av naturvitenskap}

I pollenanalysen ser vi at løvskogen forsvinner samtidig som mengden kullpartikler øker og granen innvandrer. Ettersom pollensøylen var noe forstyrret, har vi ingen sikker datering av tidspunktet, men Helge Høeg (1996, s. 125-145, tabell s. 135-137) har tidligere datert graninnvandringen i Løten til førromersk jernalder (ca. 2300 før nåtid, kal. 401-366 f.Kr. $2 \sigma$ ), og tilsvarende på Narmo i Hamar (ca. 2200 før nåtid, kal. 366-192 f. Kr. $2 \sigma$ ) (Høeg i Pilø, 2005, s. 527), mens Ulf Hafsten (1992, s. 137-139, 151) plasserer graninnvandringen i romertid (ca. 1760 før nåtid, kal. 210-383 e.Kr. 2б). Imidlertid finner Hafsten tydelig graninnvandring $\mathrm{i}$ Trysil og Engerdal i førromersk jernalder, og at Solør er dekket innen Kr.f., så dateringer av graninnvandringen i området er ikke presis. I rapporten som oppsummerer

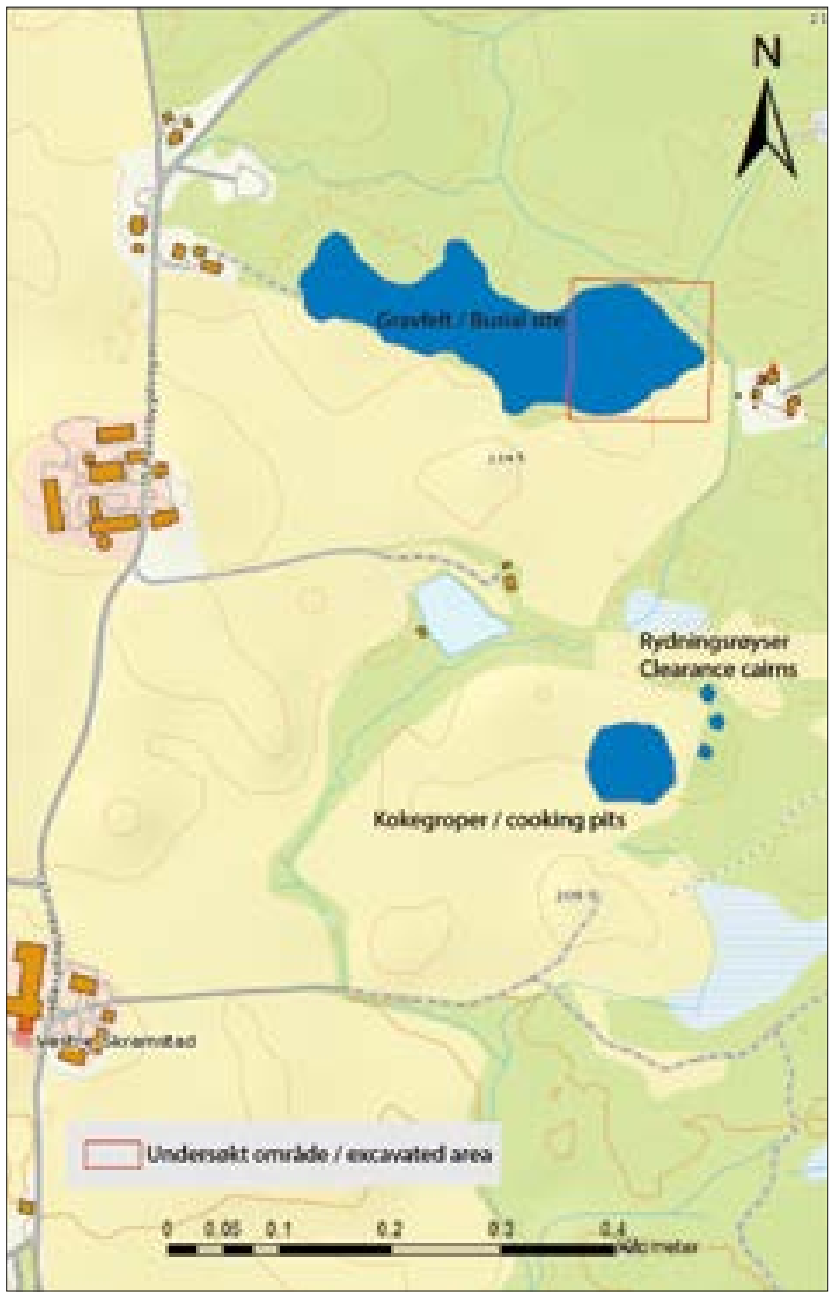

Fig. 5. Kart over nærmiljøet på Skillingstad og Skramstad. Fig. 5. Map of the area surrounding Skillingstad and Skramstad.

naturvitenskapen fra Skillingstad, konkluderes det med en innvandring i tidlig romertid, og at de to romertidsdateringene representerer synlige faser i diagrammet (Linderholm, Wallin, Östman \& Eriksson, 2017). De fem førromerske dateringene tyder likevel på en vesentlig aktivitet på feltet, og det virker derfor sannsynlig at ryddingen skjer i førromersk jernalder, og at granen innvandrer kort tid etter denne ryddingen og avsviingen av skogen. Deretter etableres et åpent landskap med lyng og gress. Det dyrkes bygg og etter hvert rug i nærheten. Vi har ingen eksakt datering av rugdyrkingen i området, men det er tydelig at dette finner sted i en fase mellom etableringen på gravfeltet og gjengroingen som begynner i slutten av merovingertid. Rugen blir først synlig i en periode etter at dyrking av bygg ble etablert i området. Antagelig tyder dette på rugdyrking allerede i folkevandringstid hvilket er uvanlig tidlig for både landsdelen og norske områder generelt. Rug ble riktignok introdusert i romertid, men dyrket i beskjeden grad, kanskje bare som et ugress i åkrene (Myhre, 2002, s. 143). Det antas at rug vant frem da kornet ble slått 
Tabell 2. Kortfattet oversikt over analyser i forbindelse med undersøkelsene av røysfelt på prosjektet. Table 2. Overview of the analysis made in connection with the excavation of cairns at the rv. 3/25.

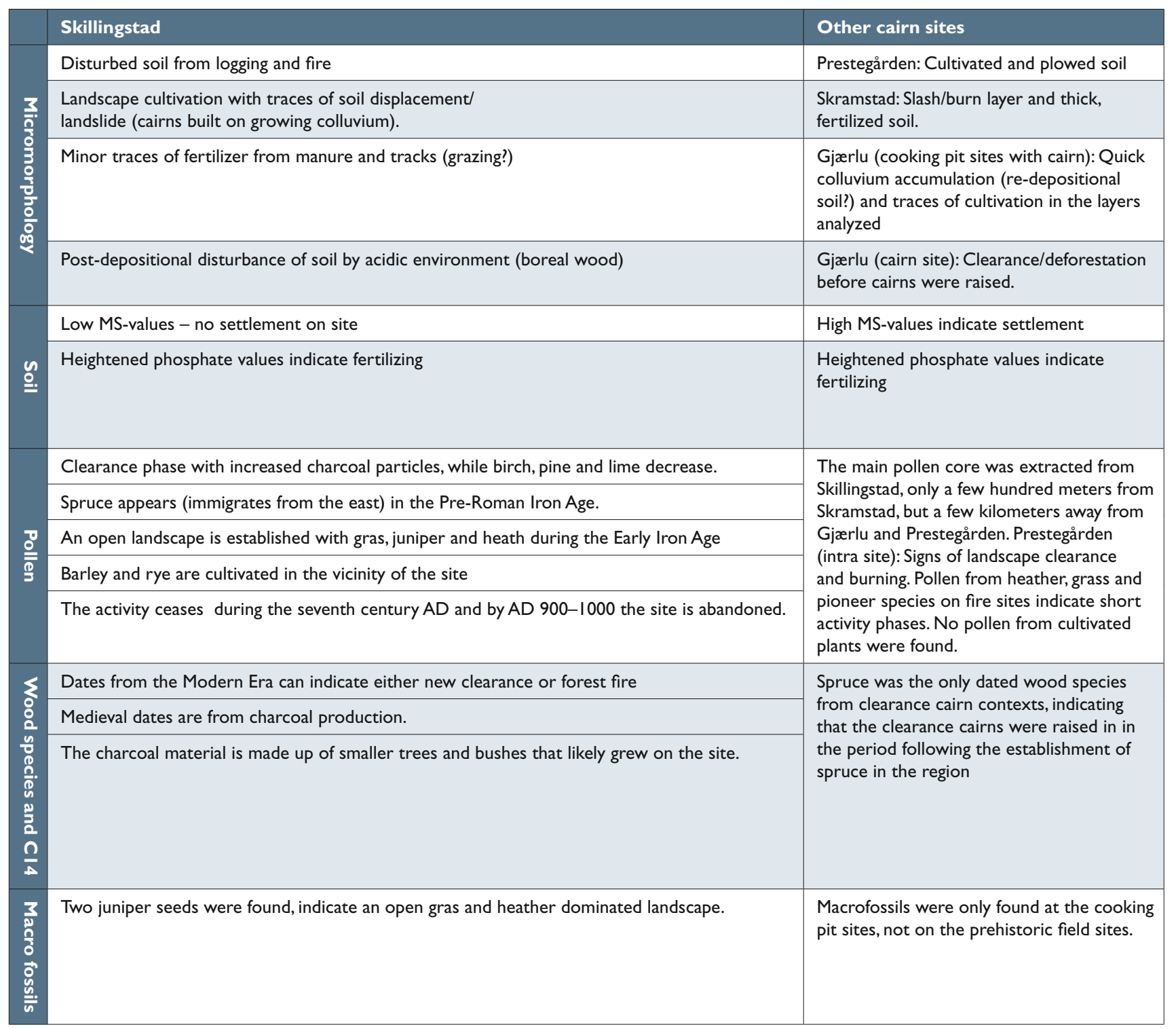

langs bakken med sigd slik at rugkornene ikke lenger ble eliminert, men inkludert blant såkornene for neste års avling. Selv om det innledningsvis var et ugress, fikk det nå en bedre spredning, og særlig i marginale områder der jordsmonn og klima var mer ufordelaktig, kunne rugen utnytte sin styrke som klimatolerant art i konkurranse med andre kornsorter. Slik kunne rugen etablere seg og utvikle seg til en ønsket kornsort i flere regioner, særlig i etterkant av folkevandringstiden (Behre, 1992). I danske og sør-svenske områder er også rug observert på boplasser i romertid, men blir først tydelig introdusert i folkevandringstid før den blir like vanlig som bygg i løpet av vikingtid (Robinson, Hambro Mikkelsen \& Malmros, 2009, s. 128-131; Grabowski, 2011, s. 485493), For områder så langt nord som Hedmark finnes ikke sammenlignbart materiale. Pollenanalysen viser videre at området legges brakk og etter hvert dekkes av barskog etter 900 e.Kr.

Som det fremgår av Tabell 2, viser de mikromorfologiske analysene vesentlige forskjeller mellom gravrøysene på Skillingstad og de andre røysfeltene. Det er ingen sikre spor etter åker på Skillingstad, bare etter gjødsling og tråkk. Resultatene skiller seg særlig fra Prestegården og Skramstad, der det er tydelig dyrkningsjord med tegn til pløying (Macphail, Linderholm \& Eriksson, 2016). Jordkjemianalysene viser de samme forskjellene mellom Skillingstad og mindre røysfelt som ble undersøkt i prosjektet. De små røysfeltene har tydelig høyere fosfatverdier som antyder bosetning og åkerbruk, mens Skillingstad har tegn til gjødsling, men ikke i mengder som kan forbindes med bosetning og fast åkerbruk (Linderholm et al., 2017). 


\section{Samlet vurdering av dateringene i prosjektet som helhet}

Ved prosjektet ble det datert kontekster relatert til agrarbosetning og utmarksaktivitet innenfor et snevert geografisk område. Alle dateringene er utført innen en radius på $3 \mathrm{~km}$. Disse dateringene strakk seg over en tidsperiode på 2000 år fra siste del av yngre bronsealder til slutten av middelalderen. Samlet sett gir disse dateringene et bilde av de langsiktige trendene i bosetningen sentralt i Løten, fra jernets innføring og økonomisk dreining mot utmarksressurser.

Totalt er det analysert 105 C14-dateringer fra lokalitetene i Løten. Det ble datert (henholdsvis) 30 prøver fra gravrøyser, 26 fra kokegroper, 18 fra kullgroper, 17 fra jernvinneovner og 14 fra dyrkningsspor. I tillegg til de 105 presenterte dateringene kommer 15 moderne dateringer. Disse 15 er for unge til å kunne kalibreres med sikkerhet (grense satt til $270 \mathrm{BP}$ ). Fire prøver som ble tatt ut fra undergrunnen på Skillingstad, og er datert til tidsrommet 8000-6000 BP, er likeledes utelatt fra statistikken ettersom de neppe representerer landnåmet i området.

Den samlede oversikten over dateringer gir et innblikk i de lange utviklingstrekkene i Løten gjennom jernalder og middelalder. (Opp)dyrkning tiltar i flere områder i starten av jernalderen samtidig som gravfeltet på Skillingstad etableres. I yngre jernalder blir utmarksressursene aktivisert samtidig som aktivitet på gravfeltet avtar, aktiviteten på kokegropfeltene forsvinner, og de fire små dyrkningsfeltene ligger brakk. Dette kan tyde på en sammentrekning av de aktive agrarmiljøene eller en konsolidering inn mot områder som ikke har vært gjenstand for undersøkelser. Samtidig ser vi at alle røysfeltene blir benyttet til kullproduksjon i middelalderen og følgelig må ha ligget brakk en god stund for å la skogen vokse til igjen. Etter at avskogingen for kullproduksjon har funnet sted, har de blitt tatt i bruk igjen for dyrkning i senmiddelalderen og inn i nyere tid.

\section{Fallet til en jernaldergård}

Et vesentlig moment i denne artikkelen er at selv om tunet på Skillingstad ikke er kjent, synes det mulig å følge livsløpet til gårdssamfunnet gjennom undersøkelsene på gravfeltet og de arkeometriske dataene fra utgravningen. Hendelsesforløpet kan sammenliknes med datagrunnlaget fra gravfeltet på By, som også omfatter områder tilhørende Englaug, og som viser en noe annen utvikling over tid. Gravene fra Skillingstad lar seg vanskelig datere på bakgrunn av artefakter, så det er i hovedsak C14-dateringene som viser brukstiden til feltet (Tabell 3). Til sammenlikning er By-feltet i hovedsak typologisk datert på gjenstander. Mens Skillingstad har en (tydelig) oppstartsfase i førromersk jernalder med fem dateringer, er det ingen distinkte førromerske funn på By. 20 graver kan imidlertid ikke tidfestes nærmere enn til perioden eldre jernalder. Romertid er godt representert på By med 17 graver før det avtar i folkevandringstid med kun to. På Skillingstad er forholdet noe annerledes med to dateringer til romertid og et klart oppsving til fem i folkevandringstid.

De to feltene er markant forskjellige ved overgangen til yngre jernalder. Skillingstad har kun et lite innslag fra merovingertid med to dateringer og to gjenstandsfunn før gravfeltet går ut av bruk i vikingtid (og etter hvert gror igjen). By-feltet har en helt annen utvikling med ni graver i merovingertid og rundt 50 i vikingtid. I yngre jernalder kommer rikdommen tydeligere til uttrykk, da flere graver inneholder sjeldne oldsaker av høy kvalitet. I flere tilfeller er det også utfordrende å vurdere hvor mange begravelser den enkelte haug på By inneholder. Den ytre konstruksjonen til røysene fra yngre jernalder skiller seg ikke fra røysene fra eldre jernalder. Mens røysene i eldre jernalder for en stor del lå i den sentrale delen av feltet, synes derimot gravene fra yngre jernalder å ha en annen og mer gruppert spredning i terrenget. Martens (1969, s. 102-103) skriver at By-feltet synes å gjennomgå en gradvis vekst og utvikling fra merovingertid og ikke lenger vokser like enhetlig som tidligere.

Dateringene og pollenanalysen fra Skillingstad viser en overgang mellom eldre og yngre jernalder. Bruken av feltet ser ut til å bli avviklet i løpet av merovingertid, og kun to C14-dateringer og to pilspisser vitner om at feltet var i bruk i merovingertid, før det faller helt ut av bruk i vikingtid.

Tabell 3. Oversikt over dateringer fra Skillingstad og By. Table 3 Overview of radiocarbon dates from Skillingstad (CI4) and By (artefact-chronology).

\begin{tabular}{|l|c|c|}
\hline Periode/Period & $\begin{array}{l}\text { Skillingstad } \\
\text { Cl4- dateringer/ } \\
\text { Datings }\end{array}$ & $\begin{array}{l}\text { By gjenstands- } \\
\text { kronologi } \\
\text { artefact hronology }\end{array}$ \\
\hline $\begin{array}{l}\text { Eldre jernalder } \\
\text { Early Iron Age }\end{array}$ & - & 20 \\
\hline $\begin{array}{l}\text { Førromersk jernalder } \\
\text { Pre-Roman Iron Age }\end{array}$ & 5 & - \\
\hline $\begin{array}{l}\text { Romertid } \\
\text { Roman Iron Age }\end{array}$ & 2 & 14 \\
\hline $\begin{array}{l}\text { Folkevandringstid } \\
\text { Migration Period }\end{array}$ & 5 & 3 \\
\hline $\begin{array}{l}\text { Merovingertid } \\
\text { Merovingian Period }\end{array}$ & 2 & 9 \\
\hline Vikingtid/Viking Age & - & ca. 50 \\
\hline
\end{tabular}


Merovingertid(en) har gjennom hele forskningshistorien vært en periode med grobunn for endringsteorier basert på både kriser, omstrukturering eller stridigheter. Overgangen mellom eldre og yngre jernalder markerer ikke bare en bruddflate i Skandinavia, men over det meste av det europeiske kontinentet (Randsborg, 1991; Ystgaard, 2014). Enten det skyldes indre dynamikk eller påvirkning utenfra, er endringsfaktorene mange. Dette er i de senere år fulgt opp gjennom teorier om naturkatastrofers påvirkningskraft, og flere har tatt utgangspunkt i en påvist klimakrise i 536 e.Kr., og at en støvsky (the dust veil event) skal ha gitt grobunn for endringer av større omfang. Den justinianske pesten som herjet Europa kan videre ha forsterket situasjonen i kombinasjon med for sterkt beite- og dyrkningspress (Gräslund, 1973; Welinder, 1975; Gräslund \& Price, 2012; Iversen, 2013; Sigl et al., 2015). Det er ikke rom for å gjennomgå alle detaljer her, men mange av endringsfaktorene i både materiell kultur og samfunnsorganisasjon er diskutert i boka The Agrarian life of the North 2000 BC-AD 1000. Studies in rural settlement and farming in Norway (Iversen \& Petersson, 2016).

En av de viktigste endringsfaktorene ved overgangen til yngre jernalder er at en rekke gårder og åkersystemer legges øde (Welinder, 1975; Rønneseth, 1981; Pedersen, 1999, s. 50; Widgren, 2012). Ødeleggingen er også satt i forbindelse med en omlegging av jordbruket og endring i eiendomsstrukturen der jord etterhvert samles under store jordegods (Skre, 1998; Iversen, 1999; Myhre, 2002, s. 191; Ljungkvist, 2006, men se også Hamerow, 2002 for europeiske eksempler). Det ser ut til at mindre gårder forlates, og store eiendommer etableres av en elite på den beste jorden rundt maktsentre, kjennetegnet bl.a. av monumentale gravhauger (Myhre, 1987, 2002). Endringer i arvereglene er mye diskutert i forbindelse med omstruktureringen. Basert på odelsrettigheter i middelalderens lovverk er det sannsynlig at rettigheter arves (Zachrisson, 1994, 2011; Iversen, 2013), men på Nørre Snede i Jylland er det trekk som antyder at retten til land reguleres fra en sentral myndighet (Holst, 2010). Det er ikke mulig å fastslå når overgangen fra primogenitur, der kun eldste arving tar arv, og senere delt arv, der gården splittes i flere enheter, fant sted, men prinsippet virker å være relevant for diskusjonen vedrørende samlingen av jordeiendommer ved overgangen til yngre jernalder.

By og Skillingstad kan betraktes som eksempler på to ulike utfall i en omstrukturering. Skillingstad besto ikke som gård, men ble liggende øde, og stedet gikk gradvis tapt i den menneskelige hukommelsen om landskapets utvikling. By-feltet synes derimot å vokse med nærmest eksplosiv fart, der nye graver virker å danne grupper til dels i sentrum, men særlig i utkanten av feltet, og dette kan kanskje forklares med at By var et av stedene makten lot seg konsolidere. Inntrykket forsterkes også ved at det på By er dokumentert sekundærbegravelser (Martens, 1969, s. 102) som dermed gir en tilknytning til eldre monumenter (se for eksempel Hållans Stenholm, 2012). Sekundærbegravelser er til sammenlikning ikke kjent inni røysene fra Skillingstad, men funnene fra merovingertid like inntil røysene kan være begravelser som forholder seg til eldre monumenter. By-feltets sentrale stilling i Løten kan dermed muligens sidestilles med Åkers posisjon. Selv om Åker oppviser stedskontinuitet tilbake til 200 e.Kr., er det særlig på bakgrunn av gravmateriale fra yngre jernalder at gården ser ut til å få et stort oppsving og vokser frem som det store maktsenteret i området i løpet av yngre jernalder (Solberg, 2000, s. 200-201).

\section{Administrative erfaringer}

Etter at utgravningene ble ferdige, har vi gjort oss noen tanker som kan være viktige å ta med i planlegging(en) av tilsvarende undersøkelser i fremtiden. Til tross for en meget god registrering, der svært få anlegg har tilkommet ved utgravning, er det enkelte faktorer som påvirket prosjekteringen. Ettersom det generelle begrepet røys ble valgt, ble undersøkelsen lagt opp som en analyse av dyrkningslandskapet på Skillingstad. Dette lot seg naturligvis endre underveis, da det ble klart at Skillingstad var et gravfelt, men medførte betydelig administrativt ekstraarbeid, i form av ny prosjektplan, utarbeiding av nytt budsjett og vedtak fra Riksantikvaren. Ukeverkene som gikk med til administrasjon, skulle egentlig ha vært brukt på utgravningen og medførte mye uro og tapt effektivitet i den innledende delen av feltarbeidet.

Anleggenes alder var også en faktor som ble debattert. Selv om sjakting hadde påvist at to av røysene lå under vollene til kullgroper, var det ikke full enighet om røysene måtte være før-reformatoriske, og et utvalg av dateringer fra registreringsfasen kunne antakelig gjort det enklere å argumentere i planleggingsfasen. Utgravningsbudsjettenes størrelse vil også påvirkes av tolkningen i prosjekteringsfasen, så i slike tilfeller vil man være tjent med at forvaltningens tre parter kan samles og enes om forståelsen av fornminnene som skulle undersøkes allerede i prosjekteringsfasen.

En siste faktor som er viktig å tenke gjennom, er definering av lokaliteter, landskapsrom og anleggstyper. På Skramstad, like sør for det store feltet på Skillingstad, 


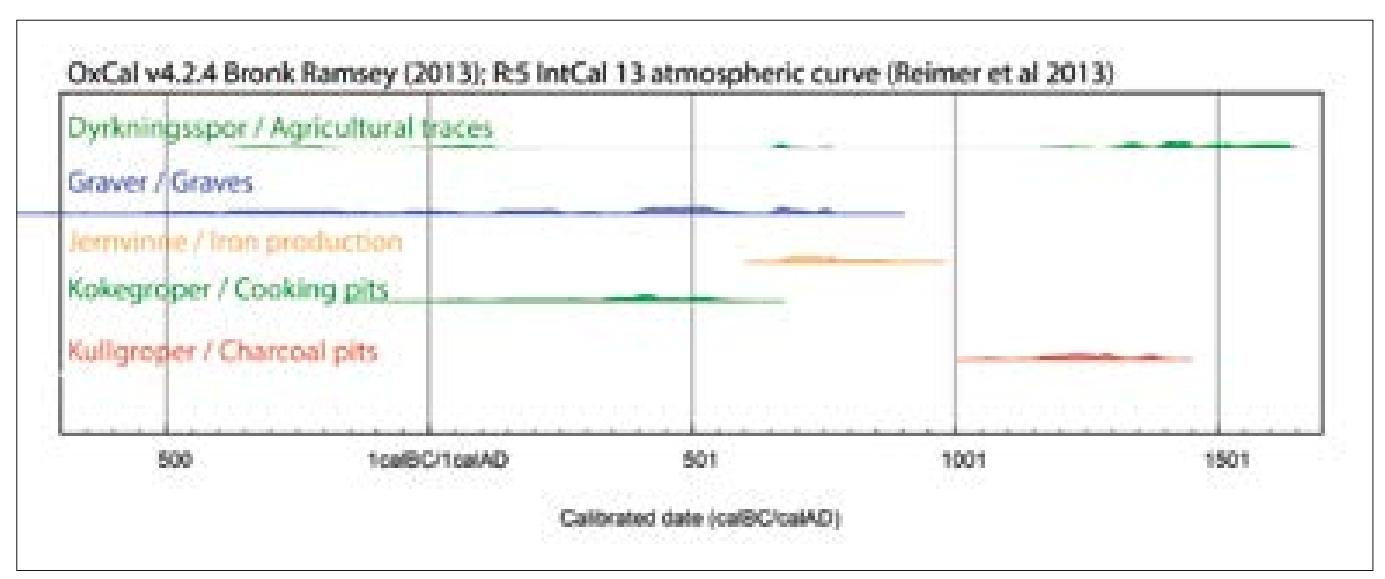

Fig. 6. Oversikt over alle dateringer på prosjektet rv. 3/25. Fig. 6. Overview of all datings from the rv. 3/25 project. ble det registrert flere enkeltliggende røyser og kullgroper, i tillegg til et kokegropfelt som ble liggende utenfor den valgte traseen. Ettersom røysene og kullgropene ble registrert enkeltvis, var det ikke mulig å undersøke områdene mellom, og det var dermed ikke mulighet for å søke etter anleggsspor i undergrunnen. Ulempen med dette ble at det ikke lot seg gjøre å finne ut om kokegropene i dyrket mark fortsatte inn i skogområdet der røysene var registrert. Etter å ha samlet dateringsmaterialet fra de enkeltliggende røysene og fra Skillingstadfeltet er det likevel klart at det er viktig å se på kulturlandskapet som en helhet. Det er overlappende dateringer mellom enkeltrøyser og dateringer på Skillingstad, og kokegropfeltet har vært i bruk samtidig med røysfeltet. I tillegg kommer smålokaliteter i LNFR $^{1}$-området. Det er sjelden at disse blir undersøkt, men fra et faglig ståsted er det problematisk at man ikke får undersøkt hele kulturmiljøet som blir berørt av tiltaket. I tillegg er det grunn til å tro at kulturminnene i dette området blir skadet av kjøring med tunge maskiner og anlegg av riggområder og liknende til tross for at det ikke er en del av selve byggeomådet. Antakelig vil arkeologien være tjent med et tettere samarbeid i tredelingen av kulturminnevernet for å unngå slike kompliserende faktorer i fremtiden.

\section{Oppsummering}

I prosjektet rv. 3/25 ble det ikke påvist spor etter gårdstun eller =bygninger, og (gårds)bosetningen $\mathrm{i}$ Løten blir derfor her belyst gjennom dyrkningsspor og graver. Mangel på graver behøver ikke antyde mangel på bosetning, men dette er det ikke rom for å debattere her. Små åkerlapper som ble undersøkt på Gjærlu, Prestegården og Skramstad er av en type som i liten grad er belagt gjennom arkeologiske undersøkelser i Norge. Lokalitetene viser at man har benyttet små

\footnotetext{
' Landbruks-, natur- og friluftsformål samt reindrift er arealformål i plan- og
} bygningsloven, omtalt i § II-7. skålformede åkerlapper som er ryddet og brent før de er pløyd og dyrket. De har vært i bruk i kort tid og ser ut til å være gjenbrukt i nyere tid. Det ligger en gevinst i at undersøkelsene fant sted innenfor et stort landskapsrom fordi det kunne samles inn materiale til analyse fra flere og ulike typer kulturminner som gir en samlet oversikt over landskapsbruken.

Undersøkelsene på Skillingstadfeltet var av særlig interesse for diskusjonen rydningsrøys vs. gravrøys, da tolkningen ble endret fra førstnevnte til sistnevnte i løpet av perioden. Tolkningen av anlegg som graver hviler på et sparsomt, men tilstedeværende gjenstandsmateriale i røysene, at røysene er anlagt på en synlig topp i terrenget, og at alle var runde, møysommelig oppbygde, konstruksjoner som lå isolert fra hverandre uten overlapping. Det ble heller ikke funnet indikasjoner på dyrkning i prøvematerialet. Feltet hadde også siktlinje til et kokegropfelt $300 \mathrm{~m}$ mot øst som var i bruk i samme tidsrom og viser at området har vært brukt av mange. Lignende store gravfelt med sparsomt funnmateriale er i liten grad undersøkt på det indre Østlandet tidligere.

Radiologiske dateringer fra røysene viser at de ble konstruert i perioden førromersk jernalder til merovingertid. Skogen vokser til, og i middelalder blir kullgroper stedvis anlagt på røyser. Kull fra toppen av røysene viser til ny avsviing på 1600-/1700-tallet. Pollenanalyser bekrefter dateringssekvensene med felling av skog som sammenfaller med graninnvandring når feltet anlegges. Det etableres et gress- og lynglandskap, og etter hvert dyrkes bygg og senere rug i nærheten. Diagrammet viser at skogen gror igjen i vikingtid og felles igjen i middelalder (slik det også fremgår av dateringene). Mikromorfologien viser videre at jorden er bearbeidet i forkant av anlegningen av røysene, og svake spor av gjødsel indikerer at det kan ha vært beitet på feltet. På grunnlag av den intensive satsningen på naturvitenskap har det gjennom prøveanalysene på Skillingstad 
vært mulig å følge og belyse livsløpet til en gård, uten at selve tunområdet er avdekket. Når Skillingstad går ut av bruk i begynnelsen av yngre jernalder, foregår det en stor omorganisering i jordbrukssamfunnet, og gården By som kun ligger noen $\mathrm{km}$ unna, får et oppsving og består gjennom hele vikingtiden.

\section{Summary}

The Rv. 3/25 archaeological excavations produced no evidence of settlements or buildings, and therefore the agrarian activity of Iron Age Løten is viewed through graves and agricultural remains, specifically in the area surrounding Skillingstad. The excavation of the Skillingstad site is of particular interest for the discussion of the distinction between burial cairns and clearance cairns. Over the course of the excavations, the interpretation of the site was changed from a clearance cairn field to a grave site. This reinterpretation is based on the presence of funerary gifts, albeit sparse, the graves' topographic placement and the internal organization of the grave site. During the excavation a great effort was put in to identifying traces of cultivation, but without any positive results, strengthening the reinterpretation as a grave field. The burial site also had a clear view to a cooking pit field 300 meters away that was in use at the same time, indicating placement within a central settlement area. Similar burial sites with sparse funerary remains have rarely been the subject of excavations and studies in the interior of eastern Norway.

The site was C14-dated using charcoal from the cairns. The dates indicate that the site was established in the PreRoman Iron Age and used until the Merovingian Period. At this point, as indicated by pollen evidence from the adjacent bog, the forest reclaimed the area and the sitelay undisturbed until several charcoal pits were constructed in the Medieval Period. Charcoal from the top of the cairns was dated to the 1600-1700s AD, and indicates a secondary clearance of the area. Several sites with small, preserved agricultural fields were studied at Gjærlu, Prestegården and Skramstad. These sites showed that small bowl shaped fields with clearance cairns were utilized and that they were cleared and burned before cultivation and plowing. They were used for a short duration, and experienced the same sequence of charcoal production as Skillingstad.

Through the use of a wide spectrum of scientific analysis we have been able to follow the life cycle of the Skillingstad farm in the Iron Age, even though settlement itself remains elusive. The abandonment of the Skillingstad site in the beginning of the Late Iron Age corresponds with a great reorganization of the agricultural settlement of Norway. The site of By, only a few kilometers away, rose to prominence and remained important throughout the Viking Age.

\section{Litteratur}

Behre, K. -E. (1992). The history of rye cultivation in Europe. Vegetation History and Archaeobotany, 1(3), 14-56. doi: 10.1007/bf00191554

Bergstøl, J. \& Loftsgarden, K. (2014). Prosjektplan. Undersøking av automatisk freda kulturminne (28 kolgroper og 21 fangstgroper). Reguleringsplan for ny rv. 3 Løten
grense-Grunset-rv. 25 Åkroken-Basthjørnet, Elverum kommune, Hedmark. Kulturhistorisk museum. Oslo.

Engtrø, D. -Ø. (2009). Rapport fra arkeologisk registrering $i$ forbindelse med reguleringsplan for rv. 3 og 25, strekningen Skillingstad-Rømma. Hedmark fylkeskommune. Hamar.

Grabowski, R. (2011). Changes in cereal cultivation during the Iron Age in southern Sweden: a compilation and interpretation of the archaeobotanical material. Vegetation History and Archaeobotany, 20(5), 479-494. doi: 10.1007/ s00334-011-0283-5

Gren, L. (2003). Hackeröri Njudungs västra hand: regional analysis och detaljstudier i Norra Sandsjö. I M. Widgren (Red.), Röjningsröseområden på sydsvenska höglandet: arkeologiska, kulturgeografiska och vegetationshistoriska undersökningar (Vol. 117). Stockholm: Stockholms universitet, Kulturgeografiska institutionen.

Grieg, S. (1918). Akerfundet I og II. Oldtiden VII.

Gräslund, B. (1973). Äring, näring, pest och salt. Tor, 15, 1972-1973, 274-293.

Gräslund, B. \& Price, N. (2012). Twilight of the gods? The 'dust veil event' og AD 536 in critical perspective. Antiquity 86, $428-443$.

Hafsten, U. (1992). The immigration and spread of Norway spruce (Picea abies (L.) Karst.) in Norway. Norsk Geografisk Tidsskrift - Norwegian Journal of Geography, 46 (3), 121158. doi: 10.1080/00291959208552291

Hagen, A. (1992). Kort innføring i Åkers arkeologi. I Økonomiske og politiske sentra i Norden ca. 400-1000 e.Kr. Åkerseminaret, Hamar 1990 (Vol. 13, s. 13-22). Oslo.

Hamerow, H. (2002). Early medieval settlements: the archaeology of rural communities in Northwest Europe, 400-900. Oxford: Oxford University Press.

Hansen, F. B. (2012). Rapport fra arkeologisk registrering i forbindelse med Statens vegvesens reguleringsplan for Riksvei 3/25 Løten-Elverum kommune. Hedmark fylkeskommune. Hamar.

Helliksen, W. (2007). Rapport fra utgraving av bryggesteinslag fra yngre jernalder, Balke, 10/2, Løten kommune, Hedmark. Rapport i Kulturhistorisk museums saksarkiv (ref. 05/8917).

Holm, I. (1995). Trekk av Vardals agrare historie. Oslo: Universitetets Oldsaksamling.

Holm, I. (2004). Forvaltning av agrare kulturminner i utmark. Bergen: Arkeologisk institutt, Universitetet i Bergen.

Holm, I. (2007). Forvaltning av agrare kulturminner $i$ utmark (Vol. 4). Bergen: Universitetet i Bergen, Institutt for arkeologi, historie, kultur- og religionsvitenskap, Det humanistiske fakultet.

Holm, I. \& Berg-Hansen, I. M. (2007). Rapport arkeologisk utgravning. Dyrkningstraseer, kullgroper, tjaremile og ulvestue. Grundset 14/3, Elverum, Hedmark. Oslo: Kulturhistorisk museums saksarkiv (ref. 05/2153).

Holst, M. K. (2010). Inconsistancy and stability - Large and small farmsteads in the Village of Nørre Snede (Central Jutland) in the first milennium AD. I GedächtnisKolloquium Werner Haarnagel (1907-1984): Herrenhöfe und die Hierarchie der Macht im Raum südlich und östlich der Nordsee von der Vorrömischen Eisenzeit bis zumfrühen Mittelalter und zur Wikingerzeit: 11-13. Oktober 2007, Burg Bederkesa in Bad Bederkesa. s. 155-179. Rahden/ Westf.: Marie Leidorf. 
Høeg, H. I. (1996). Pollenanalytiske undersøkelser $i$ «Østerdalsområdet» med hovedvekt på Rødsmoen, Åmot $i$ Hedmark (Vol. 39). Oslo: Universitetets Oldsaksamling.

Hållans Stenholm, A. -M. (2012). Fornminnen : det förflutnas roll i det förkristna och kristna Mälardalen. (15), Nordic Academic Press, Lund.

Iversen, F. (1999). Var middelalderens lendmannsgårder kjerner i eldre godssamlinger? en analyse av romlig organisering av graver og eiendomsstruktur i Hordaland og Sogn og Fjordane (Vol. 4). Bergen: Arkeologisk institutt, Universitetet i Bergen.

Iversen, F. (2013). Big bang, lordship or inheritance? Changes in the settlement structure on the threshold of the Merovingian Period, South-Eastern Norway. I J. Klápště (Red.), Hierarchies in rural settlements. s. 341-358. Turnhout: Brepolis.

Iversen, F. \& Petersson, H. (2016). The Agrarian life of the North 2000 BC-AD 1000 : studies in rural settlement and farming in Norway. Kristiansand: Portal.

Jouttijärvi, A. (2017). Jernhåndtering ved Ånestad, Løten kommune, Riksvei 3/25 prosjektnr. 220244, saksnr. 2011/12427, Report 17-01: Heimdal-archaeometry.

Kile-Vesik, J. (under arbeid). Rapport från arkeologisk utgravning, Gravrösen, Skillingstad, 7/1, Løten, Hedmark. Oslo: Rapport i KHMs saksarkiv (ref. saksnr. 2011/12427).

Linderholm, J, Wallin, J. -E., Östman, S. \& Eriksson, S. (2017). Miljöarkeologiska analyser av jord-och sedimentprover från Skillingstad, Riksvei 3/25, Hedmark fylke, Norge. Rapport nr. 2017-005: Miljöarkeologiska laboratoriet. Universitetet i Umeå.

Lislerud, A. \& Stene, K. (2007). Lille Børke - boplass fra eldre jernalder med spor etter rituelle praksiser. I I. Ystgaard \& T. Heibreen (Red.), Arkeologiske undersøkelser 2001-2002: katalog og artikler (Vol. 62), s. 119-134. Oslo: Fornminneseksjonen.

Ljungkvist, J. (2006). En hiar atti rikR : om elit, struktur och ekonomi kring Uppsala och Mälaren under yngre järnålder = En hiar atti rikR: on elite, structure, and economy around Uppsala and Mälaren in the late Iron Age (34), Uppsala universitet, Inst. för arkeologi och antik historia, Uppsala.

Lønaas, O. C., Mjærum, A., Rundberget, B., Gundersen, I. M. \& Bergstøl, J. (2014). Prosjektplan. Undersøkelse av 75 lokaliteter med fornminner. Reguleringsplan for $r v$. 3/25, Ommangsvollen - Elverum grense, Løten kommune, Hedmark. Kulturhistorisk museum. Oslo.

Macphail, R., Linderholm, J. \& Eriksson, S. (2016). Riksvei 3/25 Project (Løten, Hedmark, Norway) sites of Anestad 1 and 2, Gjcerlu, Grundset 1 and 4, Kroksti, Prestegården, Rømma, Skillingstad and Skramstad: soil micromorphology. London/Umeå: University College London/University of Umeå.

Martens, I. (1969). Gravfeltet på By i Løten, Hedemark. Universitetets Oldsaksamlings Årbok, 1965-66, 11-148.

Mjærum, A. (2012). Åkre og beitemark i Fevanggrenda - nytt om jernalderlandbruket i Vestfold. Viking, 109-130.

Myhre, B. (1987). Chieftains' graves and chiefdom territories in South Norway in the Migration Period. Studien zur Sachsenforschung, 6, 169-187.

Myhre, B. (2002). Landbruk, landskap og samfunn 4000 f.Kr.-800 e.Kr. I B. Myhre \& I. Øye (Red.), Norges landbrukshistorie, bind I. Jorda blir levevei: 4000 f.Kr.-1350 e.Kr., s. 11-213. Oslo: Det Norske Samlaget.
Nybruget, P. O. (1992). Åkerfunnet. Grav eller depot. I Økonomiske og politiske sentra i Norden ca. 400-1000 e.Kr. Åkerseminaret, Hamar 1990, (Vol. 13), s. 23-40. Oslo.

Pedersen, E. A. (1990). Rydningsrøysfelt og gravminner - spor av eldre bosetningsstruktur på Østlandet. Viking, LIII, $50-65$.

Pedersen, E. A. (1999). Transformations to sedentary farming in eastern Norway: AD 100 or 1000 BC. I C. Fabech \& J. Ringtvedt (Red.), Settlement and Landscape proceedings of a conference in Århus, Denmark May 4-7 1998, s. 45-52. Århus: Jutland Archaeological Society.

Pilø, L. (2005). Bosted - urgård - enkeltgård. Oslo: Institutt for arkeologi, kunsthistorie og konservering, Universitetet i Oslo.

Randsborg, K. (1991). Det syvende århundrede e.Kr. I P. Mortensen \& B. M. Rasmussen (Red.), Høvdingesamfund og Kongemagt. Fra stamme til stat 2 (Vol. XXII:2), s. 11-15. Århus: Jysk Arkæologisk Selskab.

Reitan, G. (2007). Rapport fra arkeologisk utgravning av kokegrop og ildsted. Karud søndre gnr. 24/1, Løten kommune, Hedmark: Topografisk arkiv, Kulturhistorisk museum.

Risbøl, O. (1997). Arkeologi i vegen. Om de nye arkeologiske undersøkelsene på Engelaug og By i Løten. Lautin, 1997, $7-23$.

Robinson, D. E., Hambro Mikkelsen, P. \& Malmros, C. (2009). Agerbrug, driftsformer og planteressourcer i jernalder og vikingetid (500 f.Kr.-1100 e.Kr.). I B. Odgaard \& J. Rydén Rømer (Red.), Danske landbrugslandskaber gennem 2000 år : fra digevoldinger til støtteordninger, s. 117-142. Århus: Aarhus Universitetsforlag.

Rønneseth, O. (1981). Den jærske garden. Framvekst, vidareutvikling og oppløysing. I K. A. Lye (Red.), Jcerboka. Bind 3 Kulturhistoria.

Schøning, G. (1778). Reise som giennem en Deel af Norge $i$ de Aar 1773, 1774, 1775 paa Hans Majestets Kongens Bekostning er giort og beskreven af Gerhard Schøning. Kiøbenhavn: Trykt paa Gyldendals Forlag.

Sigl, M., Winstrup, M., McConnell, J. R., Welten, K. C., Plunkett, G., Ludlow, F., . . Woodruff, T. E. (2015). Timing and climate forcing of volcanic eruptions for the past 2,500 years. Nature, 523 (7562), 543-549. doi: 10.1038/ nature14565 http://www.nature.com/nature/journal/v523/ n7562/abs/nature14565.html\#supplementary-information

Skre, D. (1998). Herredømmet : bosetning og besittelse på Romerike 200-1350 e.Kr. Oslo: Universitetsforlaget.

Slomann, W. \& Christensen, A. E. (1984). The Åker Find. Facts, theories and speculations. I Festskrift til Thorleif Sjøvold på 70-årsdagen, (Vol. 5), s. 173-190). Oslo.

Solberg, B. (2000). Jernalderen i Norge : ca. 500 f.Kr.-1030 e.Kr. Oslo: Cappelen Akademisk.

Welinder, S. (1975). Prehistoric agriculture in Eastern Middle Sweden : a model for food production, population growth, agricultural innovations, and ecological limitations in prehistoric Eastern Middle Sweden 4000 B.C.-A.D. 1000 (Vol. 4). Bonn.

Wenn, C. C. (2010). Rapport fra arkeologisk utgravning av bryggesteinslag, dyrkningslag og kokegroper fra jernalder og middelalder: Rapport i KHMs saksarkiv (ref. 2008/21941).

Widgren, M. (2012). Climate and causation in the Swedish Iron Age: learning from the present to understand the past. Geografisk Tidsskrift - Danish Journal of Geography, 112 (2), 126-134. 
Ystgaard, I. (2014). Krigens praksis: Organisert voldsbruk og materiell kultur i Midt-Norge ca. 100-900 e.Kr. Norges teknisk-naturvitenskapelige universitet, Det humanistiske fakultet, Institutt for historie og klassiske fag.

Zachrisson, T. (1994). The Odal and its manifestations in the Landscape. Current Swedish Archaeology, 2, 219-238.
Zachrisson, T. (2011). Property and Honour - Social Change in Central Sweden, 200-700 AD Mirrored in the Area around Old Uppsala. I L. Boye (Red.), Arkæoologi i Slesvig: Sonderband «Det 61. Internationale Sachsensymposion 2010» Haderslev, Danmark, s. 141-156. Neumünster: Wachholtz. 